\title{
Birds in the sales catalogue of Adriaan Vroeg (1764) described by Pallas and Vosmaer
}

\author{
L.C. Rookmaaker ${ }^{1}$ \& Florence F.J.M. Pieters ${ }^{2}$ \\ ${ }^{1}$ P.O. Box 124, North Riding 2162, South Africa; ${ }^{2}$ Artis Library, University of Amsterdam, Plantage \\ Middenlaan 45, 1018 DC Amsterdam, The Netherlands
}

Key words: Sales catalogue, Pallas, Vosmaer, Vroeg, nomenclature, Aves

\begin{abstract}
On 6 October 1764, Adriaan Vroeg sold hìs collection of bìrds, insects and $\mathrm{a}$ few other animals by auction. The sales catalogue was published anonymously, but contained several scientific names of birds, which have nomenclatorial standing. Only three copies of this catalogue are known. The appendix entitled "Adumbratiunculae" has previously been attributed to Peter Simon Pallas, who is quoted as author of the new names of birds. In the present note, the main text is credited to Arnout Vosmaer, on the basis of contemporary references. Where the species names proposed by Vosmaer are synonyms of those published by Pallas in the same volume, the latter are selected, because some names have been validly used before with Pallas as the author.
\end{abstract}

\section{The sale of Vroeg's collection}

Sales catalogues are important historical documents. They show the contents of a certain collection, which again is an indication of the interests of the owner. They are also necessary to trace the fate of specific objects. However, as a kind of literature, they are ephemeral by definition, to be used during the sale and then to be discarded. The authors are generally unknown, invited by the owner or the auctioneer to list the items, to gain financially or to help a friend, rather than to produce a work of scientific record. Sometimes zoologists are confronted with these documents, for instance when the compiler used a new or different name for a certain animal. This has led to numerous ambiguities, because the authorship may be dubious or the animals were described only very briefly, while often the specimens themselves are dispersed and lost.
The catalogue of the collection of A. Vroeg was first noted by Sherborn (1905) from the copy owned by Linnaeus preserved in the Linnean Society, London. Van Oort (1911) documented a second copy, in the library of the Royal Zoological Society "Natura Artis Magistra", Amsterdam (now Artis Library, University of Amsterdam). A third copy, hitherto unrecorded, is in the Royal Library in The Hague (annotated, but incomplete, missing the appendix of seven pages).

Adriaan Vroeg was one of those collectors whose name can be traced solely in literature on zoological cabinets (Engel, 1939; Smit, 1986). According to Smit et al. (1986: 296), he was baptized in The Hague on 15 July 1733 . He was deputy director of the nature- and art cabinet of Stadholder Willem $V_{\text {. }}$ and lived at the Vijverberg in The Hague, until his death on 26 November 1777. The sales catalogue shows that he owned a remarkable collection of mounted birds.

The catalogue of Vroeg's collection sold on 6 October 1764 has the following contents:

Pp. i-viii: Dutch title-page and introduction.

Pp. ix-xvi: French title-page and introduction.

Pp. 1-33: "Naamlyst der vogelen, meestendeels, geschikt naar het stelsel van den Heer Linnaeus" ("Names of the birds, mostly, arranged according to the system of Mr. Linnaeus"); including 322 bîrds, followed by 5 mammals, 3 ostrich eggs and 4 cupboards.

Pp. 34-49: "Gekorve of beenderlooze dieren" ("Articulated or boneless animals", i.e. invertebrates), divided over 29 drawers, but not described in detail. 
Pp. 1-7: "Adumbratiunculae Avium variarum praecedenti Elencho insertarum, sed quae in Systemate Naturae Illustr. Linnaei nondum extant" (Sketches of various birds inserted in the previous list, which are absent in the Systema Naturae of Linnaeus). A list of 38 species of birds supposedly unknown to Linnaeus.

According to the annotated copy in the Royal Library, on 6 October 1764, the day of the sale, items numbered 1-239 were auctioned in the morning, items 240-331 in the afternoon, making a total price of 362 guilders for the birds and 108 guilders for the quadrupeds. Vosmaer bought 87 lots for the natural history cabinet of Stadholder Willem V. The insects had been sold beforehand in a single lot.

\section{The appendix by P.S. Pallas}

The text of the final Adumbratiunculae was reproduced in full by Sherborn (1905). This is the part discussed by most previous commentators, as it contains new systematic names. Richmond (1905) gave two reasons to attribute this section of the catalogue to Peter Simon Pallas (1741-1811), the well-known German scientist who studied in Holland from 1763 to 1767 (Wendland, 1992).

First, Pallas himself much later claimed to have described in this appendix (under the name Trynga alba) the bird named Trynga tridactyla in his Zoographia Rosso-Adriatica: "unde nomine Tryngae albae a me descripta in Catal. Vroegiani append. ad umbr." (Pallas, 1811, II: 199 note). Secondly, the catalogue is quoted several times as "Pall. adumbr." in the synonymies of birds in the 12th edition of the Systema Naturae by Linnaeus (1766). There is no known correspondence between Pallas and Linnaeus, but some kind of contact is hinted at in the letter written by Linnaeus to Brünnich on 2 November 1765 (Hulth, 1916: 392) and it seems likely that it was in fact Pallas who sent the copy of Vroeg's catalogue to Línnaeus.

A third reason may be found in the copy of Vroeg's sales catalogue in the Artis Library, which is bound in one cover together with a few other catalogues and treatises. It has a handwritten list of contents, anonymous and undated, but probably dating from the 19th if not 18th century (Fig. 1). The sales catalogue is attributed to Vroeg, followed by "Pallas Adumbratiunculae". All this amounts to reasonably strong evidence that Pallas was in fact the author or at least one of the authors of the Adumbratiunculae.

\section{The main text of the catalogue}

The introduction and the main list of specimens in Vroeg's catalogue (pp. i-xvi and 1-49) have never been attributed to Pallas, except inadvertently by Wendland (1992: 992). Van Oort (1911) correctly pointed out that all 38 names contained in the Adumbratiunculae also appeared in the main body of the catalogue. He did not treat this as a very serious problem, because the entire volume was published anonymously, for which reason it "cannot be noticed in zoology". This view is no longer held in the current International Code of Zoological Nomenclature (ICZN, 1999), which admits names published anonymously before 1951 (although it is advised to enclose the names of supposed authors in square brackets, cf. Recommendation 51D). Therefore, the names published by Pallas in the Adumbratiunculae of 1764 were all preceded by the same names (or in seven cases different names) given to the same specimens in the main text of Vroeg's catalogue. The volume itself gives no hint about authorship. However, the author is known from other, recently discovered, sources: it appears to be Arnout Vosmaer.

Arnout Vosmaer (1720-1799) was an avid collector of naturalia. From 1756, he was the director of the natural history cabinet of Stadholder Willem $\mathrm{V}$ in The Hague. He lived quite close to Vroeg's residence at the Vijverberg and they must have known each other quite well. Vosmaer left a short unpublished autobiography (Memorie tot het leven van Arnout Vosmaer) with the following passage: "1764. Gaf hij in "t Hollandsch ene systematische en beredeneerde catalogus, zoo van vogelen, viervoetige dieren als gekorvene dieren ter gelegenheid der verkoping van het Cabinet van eenen A. Vroeg in 's Hage den 6. Octobr.

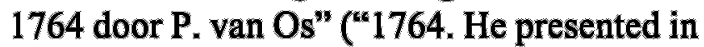
Dutch a systematic and annotated catalogue, 


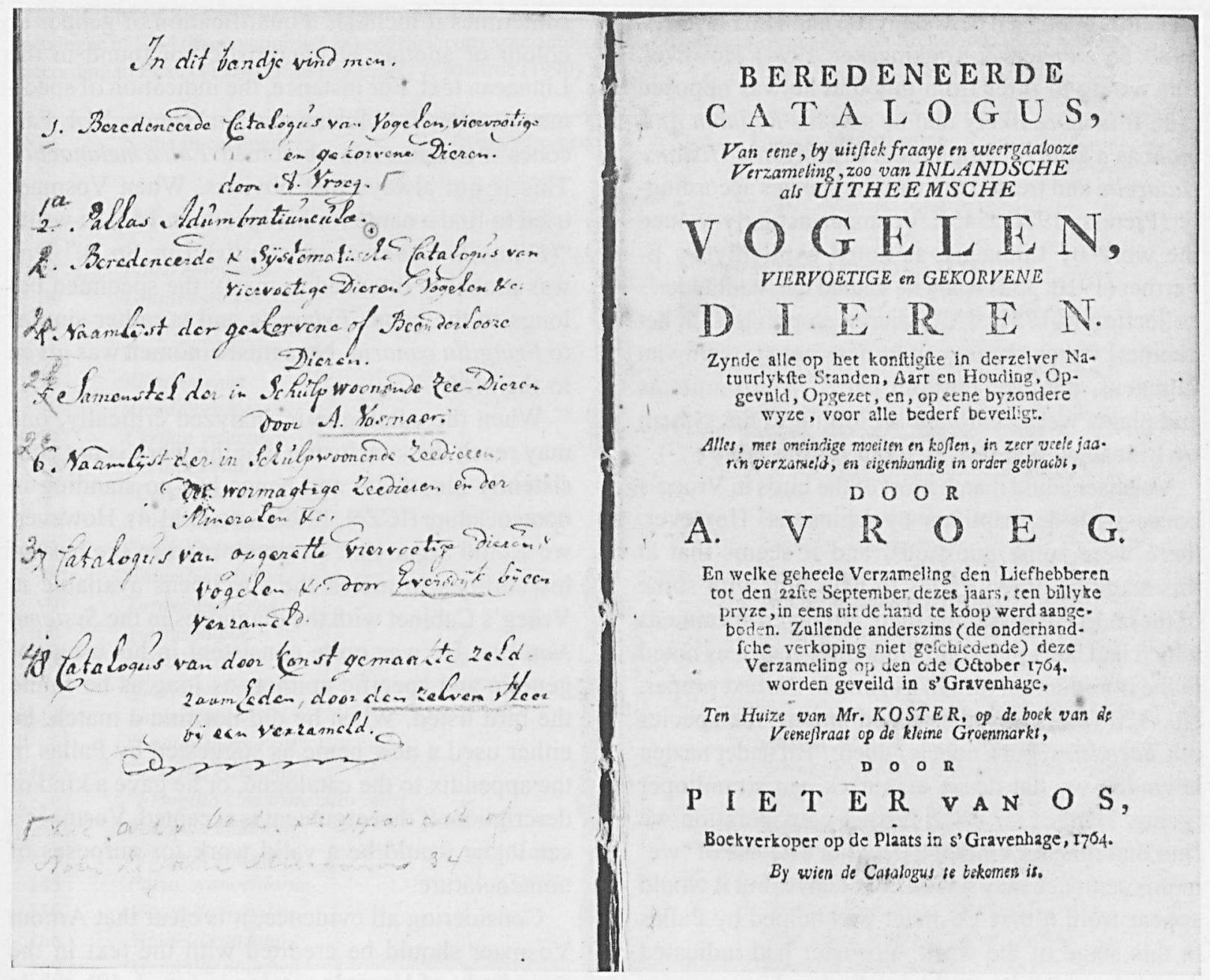

Fig. l. Facsimile of the Dutch title-page of the catalogue for the sale of the collection of Adriaan Vroeg in 1764 (photo Artis Library, University of Amsterdam). Please note the hand-written attribution of the authorship of the Adumbratiunculae to Pallas on the left page, item 2 (corrected into la).

of birds, quadrupeds as well as insects, on the occasion of the sale of the Cabinet of one A. Vroeg in The Hage on 6 October 1764 by $P$. van Os").

The same attribution was also made by Nozeman (1769: 29): "Deeze laestgenoemde [Vosmaer], weet $\mathrm{ik}$, was in 1764 de uitgeever van dien Beredeneerden Catalogus van eene bij uitstek fraeye verzaemeling zoo van inlandsche als Uitheemsche vogelen, viervoetige, en gekorvene dieren" ("The last mentioned, I know, was in 1764 the editor of that Beredeneerden Catalogus ..."). Although Nozeman did not give the name of Vroeg, there is no doubt from the title in the above quotation that he meant this sale.

Vosmaer and Pallas did not get along very well, but it appears that their animosity dates from 1766 when Pallas published descriptions of some animals in the Stadholder's collection without Vosmaer's prior consent. Before 1766, Pallas had free access to the cabinet and even took visitors around occasionally during Vosmaer's absence (Scheurleer, 1967: 25; Pieters, 1980: 540). We suggest that Vosmaer first arranged and numbered the specimens in Vroeg's house and made a rough catalogue according to the Systema Naturae by Linnaeus. The use of this system may surprise us at first sight, because Vosmaer almost never used Linnaean names in other publications. He used only a few Latin names in his Regnum Animale, a collective title for 35 descriptions of mainly new mammals 
and bìrds published between 1766 and 1805 (Pieters, 1980: 551; Pieters \& Rookmaaker, 1994). However, it is wrong to infer from this that he was opposed to it. It is more likely that he saw his Regnum Animale as a kind of supplement to Buffon's Histoire Naturelle and treated the various species accordingly (Pieters, 1980: 545), Vosmaer actually valued the work by Linnaeus, as noted explicitly by $\mathbf{B}$. Fermer (1910: 352) when he visited the Stadholder's collection in 1759: "Alle dieren en planten [in het kabinet] waren gerangschikt naar het systeem van Linnaeus, dat daar op tafel lag ..." ("All animals and plants were exhibited according to the system by Linnaeus, which was lying on the table ...").

Vosmaer could match most of the birds in Vroeg's house with descriptions by Linnaeus. However, there were some questions, and it seems that at this stage he asked Pallas to help him with some of these. In the catalogue there are seven specimens which had been placed in the wrong genus, as noted in the introduction (p. vii, xv) and in the text proper. No. 320 (p. 32), e.g., is listed among the species of Charadrius, but a note is added: "Bijj nader nazien bevinden wy dat deeze eigentlyk een strandloper [genus Tringa] is" ("On further consideration we find that this is a kind of Tringa"). The use of "we" in this sentence may not be conclusive, but it would appear from it that Vosmaer was helped by Pallas in this stage of the work. Vosmaer had indicated the birds which he could not find in Linnaeus (as "Lin. Sp. 0") and Pallas then collected these references in the appendix, translating the descriptions into Latin with some of his own additions.

\section{Nomenclatorial implications}

When we look at Vosmaer's part of the sales catalogue with modern eyes, his arrangement of the text and his usage of Linnaean names looks amateurish, to say the least. Vosmaer divided the list of birds into chapters according to the genera found in Linnaeus (1758), but instead of using the genus name as a noun in the singular sense, he puts the name in plural. The Dutch names of the specimens are followed by an indication, always in parentheses and printed in italics, which in most cáses is the specific epithet given to the bird by Linnaeus, but sometìmes it includes a qualification of gender or colour or another characteristic not found in the Linnaean text. For instance, the indication of specimen number 1, "Melanaetus" in "Genus XLI. Falcones" translates into a binomen: Falco melanaetus. This is not always that obvious. When Vosmaer tried to find a name for his specimen 142, he wrote "(Fringilla Canariae subsimilis). Lìn. Sp. 0." This was probably intended to mean: the specimen belongs to the genus Fringilla and is rather similar to Fringilla canaria. No actual binomen was given to the bird.

When the catalogue is analyzed critically, one may reach the conclusion that the work is not consistently binominal and hence has no standing in nomenclature (ICZN, 1999: Article 11.4). However, we would argue that Vosmaer tried to the best of his abilities to match the specimens available in Vroeg's Cabinet with the diagnoses in the Systema Naturae. He was quite consistent in his usage of generic and specific epithets as long as he found the bird listed. When he did not find a match, he either used a new name as suggested by Pallas in the appendix to the catalogue, or he gave a kind of description. If that argument is accepted, Vosmaer's catalogue would be a valid work for purposes of nomenclature.

Considering all evidence, it is clear that Arnout Vosmaer should be credited with the text in the main body of Vroeg's catalogue (pp. 1-49), while Pallas was responsible for the Adumbratiunculae (appendix pp. 1-7). The 38 'new' species in the appendix are listed in Table I, together with the page-references to Vosmaer's and Pallas's texts, as well as their current identifications, following Richmond (1905) and using the nomenclature in Peters's Checklist of birds of the world and the more recent work by Sibley \& Monroe (1990). The names published by Pallas are identical to those in Vosmaer's text, except for nos. 59*, 113, 114, $142,175,258$, and 320 .

In the interest of nomenclatorial stability, we hereby select in all cases the names published by Pallas in the Adumbratiunculae of 1764 to take precedence over names given by Vosmaer to the same specimens in Vroeg's catalogue of 1764. If Vosmaer's shorter indications would be considered valid, in case of specimen no. 114, Lanius purpureus 
Table I. List of birds named by Pallas in the Adumbratiunculae of 1764, with page-references to names by Vosmaer in Vroeg's catalogue of 1764 (in quotation marks) and their current scientific names. Identification mainly after Richmond (1905) and nomenclature according to Peters (1934-1986) and Sibley \& Monroe (1990).

\begin{tabular}{|c|c|c|c|c|c|}
\hline \multirow[t]{2}{*}{ No. * } & \multirow[t]{2}{*}{ Name in catalogue } & \multicolumn{2}{|c|}{ Page-reference } & \multirow[t]{2}{*}{ Current identification } & \\
\hline & & Pallas & Vosmaer & & \\
\hline 8 & Falco epicyanus & 1 & 2 & Accipiter nisus ( $\left.\mathrm{L}_{\mathrm{x},}, 1758\right)$ & \\
\hline 18 & Lanius ruficeps & 1 & 2 & Lanius senator $L_{n,}, 1758$ & \\
\hline 28 & Psittacus caudacutus & 1 & 3 & ? Brotogeris jugularis (P.L.S. Müller, 1776) & \\
\hline 43 & Cuculus serratirostris & 1 & 5 & 7 Trogon strigilatus L, 1766 & \\
\hline 54 & Alcedo aenea & 1 & 7 \# & Chloroceryle aenea ([Pallas], 1764) & \\
\hline 55 & Alcedo cristata & 1 & 7 & Alcedo cristata [Pallas], 1764 & \\
\hline 59 & Certhia virescens & 1 & $8 \#$ & Cyanerpes caeruleus (L., 1758) & \\
\hline $59 *$ & Certhia collaris & 1 & $=$ & ? Nectarinia chalybea (L., 1766) & \\
\hline$n$ & "Certhia torque rubra" & - & $8[57 *]$ & idem & \\
\hline 60 & Trochilus guainumbi & 2 & 8 & Polytmus guainumbi ([Pallas], 1764) & \\
\hline 62 & Fringilla erythrina & 2 & 8 & Amandava amandava (L., 1758) & \\
\hline 78 & Columba cristata & 2 & 9 & Goura cristata ([Pallas], 1764) & \\
\hline 99 & Turdus puniceus & 2 & 12 & Xipholena punicea ([Pallas], 1764) & \\
\hline 100 & Turdus minor & 2 & 12 & Acrocephalus arundinaceus $(\mathrm{L}, 1758)$ & \\
\hline 113 & Loxia tricolor & 2 & $=$ & Euplectes orix $\left(\mathrm{L}_{\mathrm{n},}, 1758\right)$ & \\
\hline " & "Loxia erythromelana" & $=$ & 13 & idem & \\
\hline 114 & Lanius carbo & 2 & - & Ramphocelus carbo ([Pallas], 1764) & \\
\hline$n$ & "Lanius purpureus" & - & 13 & idem & * \\
\hline 142 & Fringilla citrinella & 3 & - & Serinus citrinella ([Pallas], 1764) & \\
\hline " & "Fringilla Canariae subsintilis" & - & 15 & idem & \\
\hline 143 & Fringilla undulata & 3 & 15 & Estrilda astrild $\left(\mathrm{L}_{\mathrm{x}}, 1758\right)$ & \\
\hline 144 & Fringilla macroura & 3 & 15 & Vidua macroura ([Pallas], 1764) & \\
\hline 145 & Parus cyanochlorus & 3 & 15 & Euphonia violacea $\left(\mathrm{L}_{x}, 1758\right)$ & \\
\hline 156 & Motacilla hypolenca & 3 & 16 & Ficedula hypoleuca ([Pallas], 1764) & \\
\hline 168 & Motacilla striata & 3 & 17 & Muscicapa striata ([Pallas], 1764) & \\
\hline 169 & Motacilla plumbea & 4 & $17 \#$ & Prunella modularis (L, 1758) & \\
\hline 175 & Parus [only] & 4 & - & Euphonia chlorotica $\left(\mathrm{L}_{\times,}, 1766\right)$ & \\
\hline , & "Parus aureus" & $=$ & $18 \times$ & idem & \\
\hline 177 & Motacilla cantillans & 4 & 18 \# & Sylvia cantillans ([Pallas], 1764) & \\
\hline 179 & Motacilla, var. cantillans & 4 & 18 & idem ? & \\
\hline 222 & Meleagris mitrata & 4 & 22 & Numida meleagris mitrata Pallas, 1767 & \\
\hline 223 & Meleagris cristata & 4 & 22 & × Guttera pucherani verreauxi (Elliot, 1870) & \\
\hline 244 & Anas dorsata & 5 & 24 & Aythya marila $(\mathrm{L}, 1761)$ & \\
\hline 245 & Anas albifrons & 5 & 24 & idem & \\
\hline 248 & Anas adunca & 5 & 25 & Anas platyrhynchos $\mathrm{L}_{\mathrm{x}} 1758$ & \\
\hline 258 & Anas ferriginea & 5 & - & Tadorna ferruginea ([Pallas], 1764) & \\
\hline$n$ & "Anser Tataricus ferrugineus" & $=$ & 25 & idem & , \\
\hline 271 & Sierna albifrons & 6 & 27 & Sterna albifrons [Pallas], 1764 & \\
\hline 279 & Colymbus fuscus & 6 & 28 & Tachybaptus ruficollis ([Pallas], 1764) & \\
\hline 281 & Colymbus ruficollis ${ }^{*}$ & 6 & 28 & idem & \\
\hline 301 & Scolopax testacea & 6 & 30 & Calidris ferruginea (Pontoppidan, 1763) & \\
\hline 306 & Scolopax erythropus & 6 & 31 & Tringa erythropus ([Pallas], 1764) & \\
\hline 311 & Trynga ralloides & 7 & 31 & Actitis hypoleucos (L., 1758) & × \\
\hline 320 & Trynga alba & 7 & $=$ & Calidris alba ([Pallas], 1764) & \\
\hline$n$ & "Tringa leucophaea" & $=$ & 32 & idem & \\
\hline
\end{tabular}

\# No description by Vosmaer, only name and locality. 
[Vosmaer], 1764: 13 is here synonymized with Lanius carbo [Pallas], 1764: 2, and for specimen 320, Tringa leucophaea [Vosmaer], 1764: 32 with Trynga alba [Pallas], 1764: 7. The status of the names Parus aureus [Vosmaer], 1764: 18 and $\mathrm{Me}$ leagris mitrata [Pallas], 1764: 4, presumably senior to the current names for the supposed species, may have to be investigated further.

At least 16 names are thus attributed to P.S. Pallas from this appendix, which can be quoted as follows: "[Pallas], 1764, Adumbratiunculae, Appendix to Vroeg's Beredeneerde Catalogus", with page reference as in Table I.

\section{Acknowledgements}

Dr Jan Wattel and Drs C.S. Roselaar kindly checked details of ornithological taxonomy, which is greatly appreciated.

\section{References}

\section{Unpublished Manuscripts}

Vosmaer A. [no date], Memorie tot mijnn leven behorende. 's Gravenhage, Algemeen Rijksarchief, 2.21.271: Archỉef van de familie Vosmaer (no. 57). [See the inventory by Van Leeuwen-Canneman, 1988: 25.]

\section{Published sources}

Engel H. 1939. Alphabetical list of Dutch zoological cabinets and menageries. Bijdr. Dierk. 27: 247-346.

Ferrner B. 1910. Dagboek van zijne reis door Nederland in 1759, medegedeeld door G.W. Kernkamp. Bijdragen en $\mathrm{Me-}$ dedeelingen van het Historisch Genootschap (Utrechl) 31: 314-509.

Hulth JM. (ed.) 1916. Brefoch skrifvelser af och till Carl von Linné. Andra afdelningen: Utlândska brefvãxlingen, del 1 : Adanson-Brünnich. Upsala: A.-B. Akademiska Bokhandeln; Berlin* R. Friedländer \& Sohn.

International Commission on Zoological Nomenclature (ICZN) 1999. International Code of Zoological Nomenclature adopted by the International Union of Biological Sciences, 4th edition. London: The International Trust for Zoological Nomenclature.

Leeuwen-Canneman MC, van 1988. Inventaris van het archief van de familie Vosmaer 17e-20ste eeuw. 's-Gravenhage: Centraal Register van Particuliere Archieven.

Linnaeus C. 1766. Systema Naturae per regnum tria naturae, secundum classes, ordines, genera, species, cum characteri- bus, differentiis, synonymis, locis. [12th edition], vol. I. Holmiae: L. Salvius.

Nozeman C. 1769. Antwoord op de vraage, voorgesteld door de Hollandsche Maatschappye der Weetenschappen: Wat is "er tot nu toe over de natuurlyke historie van ons vaderland geschreeven? Wat ontbreekt "er nog aan? En, welke is de beste wyze, waarop de gemelde geschiedenis zoude dienen geschreeven te worden. Verhandelingen uitgegeeven door de Hollandsche Maatschappye der Wetenschappen te Haarlem 11 (2): 1-60.

Oort ED, van 1911. On the catalogue of the collection of birds brought together by A. Vroeg. Notes from the Leyden Museum 34: 66-69.

[Pallas PS.] 1764. Adumbratiunculae avium variarum praecedenti Elencho insertarum, sed quae in Systemate Naturae Illustr. Linnaei nondum extant. Pp. 1-7 in Vosmaer 1764.

Pallas PS. 1811. Zoographia Rosso-Asiatica, sistens omnĭum animalium in extenso Imperio Rossico et adjacentibus maribus observatorum recensionem, domicilia, mores et descriptiones, anatomen atque icones plurimorum, vol. 2. Petropoli: Officina Caes. Academiae Scientiarum.

Peters JL. [et al.] 1934-1986. Check-list of birds of the world, 16 vols. Cambridge, Mass.: Harvard University Press.

Pieters FFJM. 1980. Notes on the menagerie and zoological cabinet of Stadholder William V of Holland, directed by Aernout Vosmaer, J, Soc. Bibliography nat. Hist. 9 (4): 539 563.

Pieters FFJM, Rookmaaker LC. 1994. Arnout Vosmaer, grand collectionneur de curiosités naturelles, et son Regnum animale. Pp. 11-38 In: Sliggers BC \& Wertheim AA, eds., Le zoo du prínce. La ménagerie du stathouder Guillaume $V$. [Zutphen]: Walburg Pers, 11-38. [Bilingual; Dutch title: Een vorstelijke dierentuin. De menagerie van Willem V.]

Richmond CW. 1905. Notes on the birds described by Pallas in the "Adumbratiuncula" of Vroeg's Catalogue. Smithsonian Miscellaneous Collections 47: 342-347.

Scheurleer TH., Lunsingh 1967. De stadhouderlijke verzamelingen. In: Gelder HE van, Reedijk C \& de Vries AB, eds., 150 Jaar Koninklijk Kabinet van Schilderijen, Koninklijke Bibliotheek, Koninklijk Penningkabinet. 's-Gravenhage: Staatsdrukkerij.j, 9-50.

Sherborn C., Davies 1905. The new species of birds in Vroeg's Catalogue, 1764. Smithsonian Miscellaneous Collections 47: 332-341.

Sibley CG, Monroe BL. 1990. Distribution and Taxonomy of the Birds of the World. New Haven \& London: Yale University Press.

Smit P. 1986. Hendrik Engel's alphabetical list of Dutch zoological cabinets and menageries (second, enlarged edition). Amsterdam: Rodopi.

[Vosmaer A.] 1764. Catalogue raisonnê, d'une collection supérieurement belle d'Oiseaux, tant exotiques qu'Europeens, de Quadrupedes et d'Insectes. Empaillés, \& arrangés avec beaucoup d'art en situations \& attitudes extrèmement naturelles, \& garantis de la corruption d'une façon particulière. Le tout rassemblé \& arrangé, pendant une longue suite d'années, avec beaucoup de peines \& à grand fraix. 
par A. Vroeg. Collection qu'on offre aux amateurs entiêre \& à un prixx raisonnable, jusqu'au 22 Septembre de cette année; après l'Echéance duquel terme, elle sera vendue aux plus offrands, le 6 Octobre 1764 à la Haye, dans la Maison de Mr. Coster, au coìn du Veènestraat sur le petit Marché aux Herbes, par Pierre van Os, Libraire demeurant sur la Place à la Haye. Pp. i-xvi, 1-49, 1-7. [For Dutch title, see Fig. 1.] Wendland F. 1992. Peter Simon Pallas (1741-1811). Materialien einer Biographie (2 vols.). Berlin/New York: Walter de Gruyter.

Accepted: 7 January 2000 